\title{
SATI: A VINDICATION OF THE HINDU WOMAN.*
}

This paper is divided into three parts : the first expounds the Hindu ideals for woman; the second suggests that these ideals are by no means exclusively Indian, or even Asiatic, but have been those of all old religious, asthetic and heroic cultures, before the coming of Industrialism; and the last contrasts these views with those of industrial feminism.

I.

In the Mahabharata there is reported a most interesting conversation between Shiva and Uma. The Great God asks Shakti to describe the duties of women, addressing her, in so doing, in terms which acknowledge her perfect attainment of the highest wisdom possible to man or god-terms which it would be hard to parallel anywhere in western literature. He says :

"Thou that dost know the Self and the not-Self, expert in every work : endowed with self-restraint and perfect same-sightedness towards every creature : free from the sense of $I$ and my-thy power and energy are equal to my own, and thou hast practised the most severe discipline. o Daughter of Himalaya, of fairest eyebrows, and whose hair ends in the fairest curls, expound to me the duties of women in full."

Then She, who is queen of heaven, and yet so sweetly human, answers :

"The duties of woman are created in the rites of wedding, when in presence of the nuptial fire she becomes the associate of her Lord, for the performance of all righteous deeds. She should be beautiful and gentle, considering her husband as her god and serving him as such in fortune and misfortune, health and sickness, obedient even if commanded to unrighteous deeds or acts that may lead to her own destruction. She should rise early, serving the gods, always keeping her house clean, tending the domestic sacred fire, eating only after the needs of gods and guests and servants have been satisfied, devoted to her father and mother and the father and mother of her husband. Devotion to her Lord is woman's honour, it is her eternal heaven; and O Maheshrara,"

she adds, with a most touching human cry,

"I desire not paradise itself if thou art not satisfied with mel"

- A paper read before the Sociological Society, November 12, igis. 
"She is a true wife who gladdens her husband," says Raja Shekhara in the Karpura Manjari. The extract following is from the Laws of Manu :

"Though destitute of virtue, or seeking pleasure elsewhere, or devoid of good qualities, a husband must be constantly worshipped as a god by a faithful wife ... If a wife obeys her husband, she will for that reason alone be exalted in heaven."

"The production of children, the nurture of those born, and the daily life of men, of these matters woman is visibly the cause."

"She who controlling her thoughts, speech and acts, violates not her duty to her Lord, dwells with him after death in heaven, and in this world is called by the virtuous a faithful wife."

Similar texts from a variety of Indian sources could be indefinitely multiplied.

From the duties of woman we naturally pass to the question of status. Let us at once acknowledge, with all competent observers, that the power of women over men is far greater in India than in any industrial state in the West. We shall find, however, that this power and influence are exercised, not as in Europe by young women, or even by young wives, but by mothers and grandmothers and also by widows. "A Master," says Manu, "exceedeth ten tutors in claim to honour; the father exceedeth a hundred masters; but the mother exceedeth a thousand fathers in the right to reverence, and in the function of teacher." So Rama said, "A mother should be as much regarded by a son as is a father," and accepted Kaikeyi's decree of banishment. I cannot emphasize too strongly the fact of this influence of mothers in India, not merely over children and in household matters, but over grown-up men to whom their word is law. One might almost say that the Native States are ruled by the queen-mothers from behind the purdah.

I can hardly find a more striking illustration of these principles in Indian literature than the story of Queen Madalasa and her son Vikranta. The Purana says (Markandeya, ch. xxv) that as her son grew up day by day she instructed him from his birth, and "taught him knowledge of the Self by means of ministering to him in sickness, and as he duly acquired strength and the heart of his father he attained to self-knowledge by his mother's words." I think many Indian men have thus attained to wisdom through their mother's words; only it must be remembered that this was in the days before wisdom was identified with literacy. The social power of the Indian woman is already reduced, wherever industrial modes of thought have penetrated. What power remains, tends to pass away from the mother and the widow to more conspicuous 
and self-assertive types. Another fifty years of education in India, and the Indian mother will have no more hold over her grown-up sons than the European mother has now; she will have descended to general culture, indeed even to newspaper reading and politics.

It is a frequent complaint of militant suffragists that men claim to lead a human life independent of women, while laying down the law that a woman's life is incomplete without man. This is certainly a one-sided position. The Hindus, however, consider a man's life just as incomplete without a wife as vice versá. Marriage and parenthood is a religious duty as much for men as for women (citizens, bien entendu, not the few of either sex who shake off the dust of the world from their feet). According to Manu, "To be mothers were women created, and to be fathers men; religious rites, therefore, are ordained in the Veda to be performed by the husband together with the wife." 1 This was written perhaps about 200 A.D. and embodies older traditions. Jahangir, some 1500 years later, observed of the Hindu worman, that she was regarded as "half of a man, his companion in religious ceremonies."

Miss Cicely Hamilton, in "The Great State" (in which, by the way, I pray I may never live), remarks : "What the State has the right to demand of her will be that she, like her father, her husband, her brother, shall conduct herself decently and in accordance with its laws. What it has not the right to demand of her-either directly or indirectly, by bribe or by indirect pressure-is that she, in return for its protection, shall consider herself under any obligation to produce its future citizens." That is the keynote of modern feminism, to escape obligations. Hindus, however, hold that both men and women alike are under obligation to produce future citizens; it is a debt to the ancestors.

It is often objected that Indian girls may be married to a husband they have never seen, and conversely. This seems heartrending to an age which associates romance with courtship and not with marriage. In India, however, there is no sentimentality, though there is much deep feeling, about marriage. Indian stories begin with marriage, where industrial stories end.

The Indian theory of marriage is one of religious duty, and has very little to do with accomplishments or passion; perhaps that is why Indian marriages are so happy. We Hindus are not individualists; for two or three thousand years we have been

1. See also ch. xxi of the Markandeya Purana, and Innumenble other references. 
trained by the worship of epic heroes and heroines to approximate to an ideal type, and therefore there are not amongst us those profound variations of spiritual culture which exist in modern Europe. Of course, there is far more individuality of another sort in India than in Europe, because we have not yet experienced a generation of universal compulsory education; but that is another matter. I must also admit that differences of spiritual culture are now developing amongst us, and it will be a very long time before we are again united in what has been so well called a single spiritual feudalism; but I speak here only of non-industrial India. There, grew up men and women true to spiritual and even to social and physical type, and it is for this reason, again, that arranged marriages in India used to be so much happier than self-chosen marriages in Europe. Still another reason is that marriages take place in India at an earlier age, when individual character is more adaptable: unfortunately, however, they have now come to be as much too early in India as too late in Europe.

That a woman should merge her individuality in that of her husband's appears intolerable to industrial minds. The industrial mind, indeed, possesses no language for the expression of a standpoint quite incomprehensible; it can anly speak of "the deep-seated desire of the average man to despise the partner of his joys and sorrows" (Cicely Hamilton, loc. cit.).

There are other modes of thought in Asia; such modes as made possible the death of General Nogi and his wife, the renunciation of a thousand saints, the immolation of a thousand widows,-modes that have disappeared from Europe since self-assertion was adopted as the basic principle of life. The expression of individuality is not a matter to which the Orientals attach any importance. Are they not always seeking to distinguish the self from its temporary forms and to escape from this all-too-insistent I and My? I spoke just now of the wisdom taught by Madalasa to her son. What was that wisdom? One day, when her baby lay on her lap crying, she said :

" My child, thou art pure and nameless; that thou hast been given a name is but a fantasy. This thy body, built of the five elements, is not in sooth thine, nor dost thou belong to it. Wherefore dost thou weep ? or maybe it is that thou dost not weep; it is a sound self-born that comes out through the king's son .... On earth is the vehicle, in the vehicle the body, but in the body another self. The sense of 'This is mine ' does not exist therewith, as it exists in the body. Ah, shame on this delusion."

It should not be forgotten that not only are these profound words placed in the mouth of a mother, but that the Puranas are popular 
works, especially familiar to all the illiterate and unlearned. All Indian religious literature is filled with this polemic against the confusion of personality with Being. But let us refer only to one expression of the same thought in life. There is not known the name of a single one of India's great painters or sculptors; and it was a constant practice of authors to suppress their own names and ascribe their work to some one better known, usually to an almost mythical poet, in order to secure the better circulation of their ideas. From first to last, there is not in Sanskrit literature a single autobiography. This anonymity, I think, is one of the proudest distinctions of our race. Perhaps now, if we realise how indifferent Indian men have been to the perpetuation of their own names, how constantly they desired identification with a greater Self, an identification which they called freedom-freedom, that is, from this very sense of individuality we are considering; then it will not appear so strange that Indian women also desire, and still desire, to remain unseen and nameless. It is ever the way of those who are conscious of a sufficient inner life, to be indifferent to outward expression of their own or any other changing personality. That it is a fact that Indian women conceive the love of man in this profound sense, is sufficiently proved by the universal acceptance in India of woman's love for man, as the one sufficient and natural symbol of the surrender of the soul to God, of the overlooking of all difference, of the merging of the finite in the infinite.

It is a most important phase of Hindu culture, that no difference of spiritual dignity was made, as between woman and man. The claim of the Buddhist nun: "How should the woman's nature hinder us?"' has never been systematically denied in India. It would have been contrary to the spirit of Indian culture to deny to individual women the opportunity of saintship or learning in the sense of closing to them the schools of divinity or science, as was attempted in the West. But marriage and parenthood being the normal duty of men and women alike, it could only have been in exceptional cases that the latter specialised in divinity (like Auvvai, or the Buddhist nuns), in science (like Lilavati) or in war (like Chand Bibi, or the Rani of Jhansi). Those set free to cultivate expert knowledge of science or to practise with undivided allegiance either religion or any art, could only be the sannyasini, the widow, and the courtesan. A majority of women have always, and naturally, preferred marriage and motherhood to either of these conditions; but those who desired to give up their world, and become sannyasinis, those from whom a husband's death took

1. C. F. Rhys Davids, "Psalms of the Early Buddhists," 1909, p. 45. 
away the central motif in their life, and those trained from childhood as expert artists, have always maintained a great and honourable tradition in the various branches of cultured activity, as philosophy, social service, music.

What it is important to observe is that Indian society has always regarded these specialisations as more or less incompatible with wifehood. Modern experience entirely justifies this intuition, for not only is it becoming daily more evident that to do any one thing perfectly requires the devotion of a whole life, a complete concentration of attention, but we find in actual fact that some 75 per cent. of Western graduate women do not marry; and certainly, industrial conditions on the one hand and devotion to social pleasures (or duties) on the other, more and more unfit a majority of women for efficient motherhood.

We have already spoken of mythology; and I think the position of woman in Indian mythology must have struck you as very remarkable. It is only in the earliest Greek thought that we find any such ideal of high companionship. Semitic preoccupations now make it almost impossible for Western minds to conceive an Overlord equally male and female; yet this is the Hindu conception of God. "Know everything which is male to be Shiva," says the Mahabharata, "and all that is female to be Uma: for this whole world, both active and inert, is pervaded by these persons twain." There are many dual images of the sculptor and the poet in which this divine duality is very fully expressed; and even in other idols, the woman-half is usually implied in the woman's earring which the god wears in his left ear. More often still the two are separately represented as Shiva and Shakti; and perhaps half the Hindus are Shaktas, and naturally speak of God as She. The deep theory of shakti (energy) is enduring evidence of the spiritual status of the Hindu woman. She is at once half of God and mother of all gods and men; without her power, not even Shiva can perform his dance. At times, indeed, she seems in her activity to leave only a quite secondary role for Shiva himself. She is the most militant of all feminists and it is ever she who fights the demons, while the male gods stand aside and watch the battle. Often, too, it is she who as Kali dances the dance of destruction at the close of an æon. But she is also an ideal Hindu wife, and the first Sati, and shy beyond words; she is Shiva's humblest servant, desiring no good in heaven or earth beyond his welfare. She is in truth an image of Indian woman.

These mythological images are chosen deliberately as the truest reflection of the inner life of the Hindu woman. For the whole inner life, with which no anthropologists, and nowadays, it is to 
be feared, too few reformers, are concerned, is the essential subject matter of the poets, with whom the imager is also to be reckoned. In India, we pray to Shiva as "Thou that dost take the forms imagined by thy worshippers": and in view of such a lecture as Professor Geddes delivered here a month ago, I need not labour the point that the heroic figures of mythology reflect the conditions of human society. It is from this point of view that I show you upon the screen illustrations of Hindu mythology, so far as it uses waman-forms as the symbols of its thought. With these are included other pictures nominally secular, but in which race types of thought are clearly reflected--for all art which is not realistic, is by the same token mythological.

Let us now return to the Indian Sati, and try to understand her better. The root meaning of the word is essential being, and we have so far taken it only in a wide sense. But she who dies for a husband is also called Sati in a more special sense. It is in this special sense only that the word is well known to European readers. It is this last proof of the perfect unity of body and soul, this devotion beyond the grave, which western critics have chosen as our reproach. They were right in attaching so much importance to it; we only differ from them in thinking of our Satis with unchangeable respect and love, rather than pity.

The suggestion is sometimes made, that if it be right to die for love at all, why should not men also die? Those who believe that an institution like Sati could anywhere have been imposed by men upon women, against their nature, may well believe that men at the same time laid down for themselves a different and more agreeable law. There are some who have gone further, and found a reason for the custom imposed by men on women, in the belief of the former that the latter might, for various reasons, desire their death, and would compass that end were they not deterred by fear of their own. We need not consider either of these, since it passes the wit of man to answer a fool according to his folly. But we may inquire why it is, that what in a woman excites our enthusiasm and wonder, in a man is usually felt to be cowardice. The deep reasons for this lie beyond the realm of individual advantages. The human spirit, pursuing its ends deliberately and wisely, demands of men and of women two different devotions. It asks of women devotion to men; of men, devotion to ideas. In each devotion lies an equal glory and an equal joy. There is no difference in degree of devotion between that Sati who won the consent of an English Governor to her fiery death, by calmly holding a finger in the flame of a candle till it shrivelled to a cinder, and that English martyr who in like wise proved his readiness for 
the stake. From an Industrial standpoint, both devotions are equally useless.

Now that more than eighty years have elapsed since Sati was legally suppressed in India, as the result of an agitation led by Raja Ram Mohun Roy, it should not be difficult to review its history and significance more dispassionately than was possible while it still continued. As the basis of such an inquiry we may take the very interesting Persian poem which was written by Muhammad Riza Nau'i at the Mughal court about I6IO A.D., upon a Hindu girl whose betrothed was killed on the very day of their marriage. She refused to be comforted, and wished to burn herself an his pyre. Akbar was informed of this event, and calling the girl before him, offered her wealth and protection. She refused these indignantly, and would neither speak nor hear of anything but Fire. Akbar was forced, though reluctantly, to give his consent to the sacrifice, but sent with her his son Prince Daniyal, who continued to dissuade her. Even from amidst the flames, she replied to his remonstrances, 'Do not annoy, do not annoy, do not annoy. 'Ah,' exclaims the poet :

"Let those whose hearts are ablaze with the Fire of Love learn courage from this pure may!

Teach me, $O$ God, the Way of Love, and enflame my heart with this maiden's Fire."

Thus he prays for himself : and for her :

" Do Thou, O God, exalt the head of that rare hidden virgin, whose purity exceeded that of the Houris,

Do Thou endear her to the first-kissing of her King, and graciously accept her sacrifice."

Thus, like every mystic, he identifies sacred love and profane, knowing that both are alike a recognition of Unity. It is, indeed, very noteworthy that this Musulman poet, for whom the Hindus were 'idolaters' relates his story in no spirit of religious intolerance; his attitude is one not of horror, but of wonder, 'that after the death of men, the women show forth their marvellous passion.' The modern critic, it seems, can imagine no motif but self-interest underlying a social phenomenon that passes their comprehension : Nau'i perceives in it only the working of Love. He is amazed, not at the wickedness of men, but at the greatness of women. The association of Love and Fire is to him very simple. He knows that Love and Life are opposing forces, that the soul must leave all to follow, and so it is very easy for him to write of this Sati in his own burning language of Suf mysticism. He sees clearly that 
it is the same irresistible call that leads the Sati to the flames and the Yogi to the desert. With great skill, then, he takes the things of which intolerance makes a reproach, and weaves from them a garland of enduring praise : Love is the image worshipped by these idolaters, and the flame that scorches these fire-worshippers. Perhaps Nau'i had pondered some such saying as that of Shaikh Mahmud Shabistari :

" Did the Mussulman understand what the Idol is, He would know that there is religion even in idolatry."

But it is the Sati, rather than the poet, that we wish to consider here. I have no statistics of their numbers; but I suppose that never more than one in a thousand of Indian widows actually died by fire or otherwise. Some say that long ago there was no .physical fire, but two lives were so closely bound together (and this idea constantly recurs, with similes such as that of rivers joining) that when one ceased, the inward fire of love consumed the other; and it is on these lines that all mystical interpretations run. But instead of developing this line of thought, which would take us far afield, let us consider some other actual cases of Indian sati. In Tamil literature we read of one who replies to the Brahmans who would dissuade her, that since her lord is dead, the cool water of the lotus-pool and the flames of the funeral pyre are alike; while another begs to share her hero's grave, saying to the potter that she has fared with her lord over many a desert plain, and asking him now to make the funeral urn large enough for both. Later in Indian history we read of the widowed mother of Harsha, who replies to her son's remonstrance: "I am the lady of a great house; have you forgotten that I am the lioness-mate of a great spirit, who, like a lion, had his delight in a hundred battles?"1

In medixval times we have the great stories of Padmavati and other Rajput heroines who chose for themselves a fiery death, when their warriors put on the saffron robes of renunciation and themselves went out to an inevitable death : an equal ecstasy must have inspired both.

Matter-of-fact accounts of more modern satis are given by Englishmen who have witnessed them. One which took place in Baroda in 1825 is described 2 by $R$. Hartley Kennedy, the widow persisting in her intention in spite of "several fruitless endeavours to dissuade her." A more remarkable case is described by Sir Frederick Halliday. Here also the widow resisted all dissuasion,

1. Bana : Harsha Charita, trans. by E. B. Cowell and F. W. Thomas, ch. $v$

2. "The Sutti, as witnessed at Baroda," by R. Hartiey Rennedy, London 1855. I am indebted to the kindneas of Mr. A. G. Ellis for this reference. 
and finally proved her determination by asking for a lamp, and holding her finger in the flame until it was burnt and twisted like a quill-pen held in the flame of a candle; all this time she gave no sign of fear or pain whatever. Sir F. Halliday had therefore to grant her permission, even as Akbar had been forced to do three centuries earlier. Soon afterwards sati was prohibited by law (in 1829). $^{1}$

Mark now, that this great courage, this high spirit and faith even unto death, was shown by women who were not what we now call free, but by those whose greatest honour was to be least known, for whom marriage was a dedication as absolute as any nun's. These women, who when occasion demanded became the leaders of armies and the captains of desperate defences, or, when all was lost, went serenely and gladly to a death that seemed to them far sweeter than a half-life, were no Amazons, were not accustomed, even to the smallest extent, to share in the public life of men. Their whole life was one of self-devotion. The ideals they accepted were those of Sita, of Savitri, of Parvati, of Radha. They believed with all their hearts that for them the highest religion was to worship their own husbands as their gods. They did not stop to ask if men were worthy of this; their thought was of service. Sati was no isolated phenomenon in the life of Indian women : only the perfect devotion of their life made possible and easy the final choice of death.

It is sometimes said that at certain times or places in Indiaamongst the Buddhists, or the Mahrattas, or in the epics,-there was no purdah; or that certain historic individuals were not secluded. Such statements, even when literally true, ignore the fact that there are other kinds of seclusion than those afforded by palace walls. For example, though Rama, Lakshman, and Sita lived together in forest-exile in the closest intimacy for many years, it is expressly stated that Lakshman had never raised his eyes above his brother's wife's feet, so that he did not even know her appearance; while, to take a more general illustration, it is customary for Indians, when occasion arises for them to address an unknown woman, not a relative, to call her 'Mother,' irrespective of her actual age. We speak here of the inner life; and for that life, these unseen walls are a seclusion equally absolute with any purdah.

Such is the being whose perfection I would set before you. And if after all you are not convinced, and turn upon us and say

1. Buckland, "Bengal under the Lientemant_Governors," Calcutta I901, p. 160. 
that she is a slave, and that we Oriental men have made her what she is, we can only reply once more that we do not identify freedom with self-assertion, and we think that the Oriental woman is what she is, only because our social and religious culture has permitted her to become and to remain essentially feminine. We should scarcely dare claim for ourselves the whole honour of creating such a type, however persistently the Industrial critic would thrust it upon us.

\section{II.}

I should like to make it very clear that I am not advancing any argument for the superiority of the Eastern above the Western woman in her innermost nature; it is rather as the representative of an universal type, from which the Industrial woman has departed, that I would speak of her. We may not claim that no women in the world have ever been so strong, so sweet, so utterly devoted as those of India, nor that Indian women must ever remain so, merely because they are Indian. For this perfection of nobility in women depends not on race, but upon ideals : it is the outcome of a certain view of life.

Savitri, Padmavati, Sita, Radha, Uma, Lilavati, Tara-our divine and human heroines-have an universal fellowship, for "everything that is feminine is from Uma." Who could have been more wholly devoted than Alcestis, more patient than Griselda, more loving than Deirdre, more soldier than Joan of Arc, more Amazon than Brynhild?

As I am writing these words, there comes the news of the sinking of the Titanic, with the story of more than one woman, perhaps as many as forty, who refused to be rescued without their husbands, or were only torn from them by force-dramatic confirmation of the conviction that love-heroism is always and everywhere the same, and not only in India, nor only in bygone ages, may prove itself stronger than death. I cannot even doubt that if sati were permitted by European tradition at the present day there would be found some western worshippers of fire whom no dissuasion could deter. I do not think that the Hindu woman-ideal has ever been the exclusive treasure of a single race or time, but rather, it reappears wherever woman is set free to be truly herself, that is, wherever a sufficiently religious, heroic, and asthetic culture has afforded her the necessary protection. 1

The cry of our Indian Sati, 'Do not annoy,' and 'No one has any right over the life of another: is not that my own affair?' is no cry for the protection against a fate she does not seek : it is the

1. Cl. Lafcadio Hearn, "Japan," p. 393 ff. 
cry of all the women of the world who have followed love beyond the grave. Deirdre refused every offer of care and protection from Conchubar: "It is not land or earth or food I am wanting," she said, "or gold or silver or horses, but leave to go to the grave where the sons of Usnach are lying." Emer calls to Cuchullain slain : "Love of my life, my friend, my sweetheart, my one choice of the men of the world, many is the women, wed or unwed, envied me until to-day, and now I will not stay living after you." 1

Irish women were free enough. But we are used even more to look on the old Teutonic type as representative of free and even amazonian womanhood. We do not think of Brynhild, ShieldMay and Victory-Wafter, as compelled by men to any action against her will, or as weakly submissive. Yet she too became Sati when Sigurd was slain. The prayers of Gunnar availed as little as Conchubar's : he "laid his arms about her neck, and besought her to live and have wealth from him; and all others in like wise letted her from dying; but she thrust them all from her, and said that it was not the part of any to let her in that which was her will.". There is another great woman in this Teutonic saga, she who was wedded to Sigurd: and when be was betrayed, she cried :

Now am I as little

As the leaf may be

Amid wind-swept wood,

Now when dead he lieth. $s$

Mediæval religion reflects the same epic and heroic ideals for woman-ideals as remote from those of St. Paul, as they are close to Indian. Two quotations must suffice; both relating to Mary Virgin :

There is no rose of swich vertu

As is the rose that bare Jhesu : Alleluia.

For in this rose conteined was

Heven and erthe in litel space: Alleluia.

And again : -15th Century carol.

She who is courteous in her mind, with shyness shall her face be bright: of all the beauties of the body, none is more shining than shyness.

-Shacktafelsk, quoted by Yrjo Hirn, Tho-Sacked Shrine.

1. First Iay of Gudrun, translated by Wilitm Morris.

2. "Cuchultuin," version by Irady Gregry.

3. Volsunga Saga, translation by Willam Morris. 
This theory of courtesy, of supreme gentleness-" "full sweetly bowing down her head," says the English Merlin, "as she that was shamefast"-runs also through all medizval chivalry. Yet it is about this shy quiet being, a mystery to men, that the whole medizval world turns : "first reserve the honour to God," says Malory, "and secondly, the quarrel must come of thy lady." Like Uma and Sita, Mary Virgin is the image of a perfect being; and for a little while, in poetry and architecture, we glimpse an idealisation of woman and woman's love akin to the praise of Radha in the contemporary songs of Chandidas and Vidyapati.

But even more significant than the religious and knightly culture, for our purpose, the product of less quickly changing conditions, more impressive also in its naiveté, is the picture of the woman-type amongst the folk, which we can gather from folksong and lyric. The woman of the people was obviously strong and sensible and by no means economically a parasite. If we study the folk-speech, however, anywhere in the world, we shall find that it reveals woman, and not man, as the lover; when her shyness allows, it is she who would pray for man's love, and will serve him to the utmost. Industrialism reverses this relation, making man the suppliant and the servant, a condition as unnatural as any other of its characteristic perversions.

The woman of the folk does not bear resentment. Fair Helen, who followed Child Waters on foot, and bore his child in a stable, is overheard singing :

Lullabye, my owne deere child!

$I$ wold thy father were a king,

Thy mother layd on a beere.

Is she not like the Bengali Malanchamala, whose husband had married a second wife, and left her unloved and forgotten ?-who says, "Though I die now, and become a bird or a lesser creature, or whatever befall me, I care not, for I have seen my darling happy."

If woman under Industrialism is unsatisfied, it would be difficult to say how much man also loses. For woman is naturally the lover, the bestower of life :

Conjunction with me renders life long;

1 give youth when I enter upon amorousness.

$\rightarrow$ Nizami.

Her complaint is not that man demands too much, but that he will accept too little :

Long time have I been waiting for the coming of my dear;

Sometimes I am uneasy and troubled in my mind, 
Sometimes I think I'll go to my lover and tell to him my mind.

But if I should go to my lover, my love he will say nay,

If I show to him my boldness, he'll ne'er love me again.

-Eastern Counties Folk-song.

And it is to serve him, not to ask service from him, she desires:

In the cold stormy weather, when the winds are a-blowing, My dear I shall be willing to wait on you then.

-Somerset Folk-song.

This Oriental woman, then, whom you all agree to pity so deeply, is not Oriental at all, but simply woman; she is your own self. If you accept this revelation, if you see your inner self thus reflected in a mirror, perhaps you will wish to set out in search of a new emancipation, something other than you now desire; not an escape from love, but a way out of Industrialism. We ought even to undertake this quest together.

111.

I think you modern women of the West are fully justified in your revolt. For what has modern industrialism not robbed you of? It has made possible for a few, and only a few, more physical comfort and greater security of life : but it has robbed those very ones of the power to walk, or dress, or marry, or desire children or even lovers, or to believe in any power not legally exteriorised. Decade after decade since the fourteenth century has seen your influence lessened. Your influence was once paramount in religion, in poetry, in music, in architecture and in all life. But men, when they reformed the church and taught you that marriage, or sexual love, was no sacrament; when they took your music and forced it into modes of equal temperament; when they eliminated emotion from education and set up knowledge as their god'; when they asked you to pinch your waists and feet, and persuaded you to think this a refinement, and to think the language of Elizabethan poetry coarse; when at last they taught you to become Imperialists, and went away alone to colonise and 'civilise' leaving a million and a half of you in England with nothing particular to do; when, if you have the chance to marry at all, it is generally five or ten years too late;-who can wonder that you are dissatisfied, and claim your right to a career of your own, "not merely in order to earn your livelihood, but to provide yourselves with an object in life" ?2 To receive the franchise is the least compensation due to

1. Cf. "The Great State," p. 127.

2. From an advertisement of the Englishwoman's Year Book, rorx. 
you. You have good cause of resentment, but I think you mistake in directing that resentment against men. It is not men, but Industrialism and Imperialism that have cheated you of life, and have equally cheated men. These cannot be permanent conditions of life; and they are not a normal product of man's nature, any more than of woman's, but rather a snare in which both have been taken. You have forgotten, and man himself has forgotten his true nature; but you will never recover your place in the world till you find it again and adore it-until your conception of perfect freedom becomes again a conception of absolute selfdedication.

Meanwhile there is one profound weakness in your movement towards emancipation. Your whole argument is based on an acceptance of male values. You nominal ferninists are as much enslaved by male ideals, as we so-called Indian nationalists are. enslaved by European ideals. Like man, you value, desire, industry, and not leisure; you aim to externalise your life in every way; success in men's professions is your goal; you are ashamed of your sexual differentiation; you claim to be as reasonable, as learned, as expert as any men, and your best men friends make the same claim for you. In fact, you have no feminine idealism whatever, and proportionately little power over men.

Perhaps I can make this point clearer by calling your attention to an Indian parallel. I think the claims of our Indian politicians are entirely justified, as much justified as woman's claim to share the loaves and fishes with Industrial Man. But they express no sort of national idealism. The Indians and their English friends demand certain rights on the grounds that the Indian can do, or can learn to do, certain things as well as an Englishman (a view I do not admit, for the Indians are not good Industrialists). Just in the same way women and their male supporters demand their rights on the ground that they can do, or learn to do the work of men as well as men themselves-(a view I also deny). Both arguments imply a profound self-distrust. The claim to equality with men-what an honour! that men should grant the claim-what condescension! But surely this is rather a matter of taste than of fact? If there is one profound intuition of the non-industrial consciousness, the philosophical or religious consciousness, it is that the qualities of men and women are incommensurable. "The sexes are differently entertained;" says Novalis, "man demands the sensational in intellectual form, woman the intellectual in sensational form. What is secondary, to the man is paramount to the woman. Do they not resemble the Infinite, since it is impossible to square 
(quadriten) them, and they can only be approached through approximation ?" It is the Hindu view, not that men and women should approach one type of temperament and occupations, but that for the greatest abundance of life, there is requisite the greatest possible sexual differentiation. "To deny here," says another of your own teachers, in the same way, "the profoundest antagonism and the necessity for an eternally hostile tension, to dream here perhaps of equal rights, equal tyranny, equal claims and obligations : that is a typical sign of shallow-mindedness."

What is it that great men, poets and creators, not men of analysis, demand of women? It is certainly their requirements which are of most significance for the human race, which advances from camp to camp under the guidance of leaders, and not by accident. The one thing which they ask from women is Life. ${ }^{1}$ The greatest men have been inspired by the simplest women. Was it her learning, or her natural magic that made Beatrice Dante's shakti? or was it for her knowledge that Chandidas worshipped a blanchisseuse? Who of all the young girls of Ireland did Cuchulain choose? It was Emer, for she had the six gifts-of beauty, of voice, of sweet speech, of needlework, of wisdom, and of chastity. What do we know of Helen? Only this, that 'strangely like she was to some immortal spirit'; in a word, that she was radiant. Radha's brightness makes the ground she stands upon to shine like gold.

Hire luve lumes liht

As a launterne a nyht.

says the old English poet. It is this radiance in women that urges men to heroism of every kind, be it martial or poetic. Even amongst men who are only relatively great, those who are leaders even of small companies, we very rarely find that they seek to marry women who excel in the same direction : it is not camaraderie that one needs of woman, it is magic.

I have tried to show from the folk-song and epic of all nonindustrial cultures that it is a part of woman's innermost will to worship man. But they cannot worship those who are not aware of their need of such adoration, and it is just the very self-sufficiency of Industrial man which makes him unable to save the woman in woman. It is not surprising that modern woman cannot adore Industrial man; it is surprising, however, that she wants to be like him. It would almost appear as if Industry were a contagious

r. Behold my life, in which is flashing ruby;

In which is many a fountain of the water of life. - Nisami. 
disease. It is not possible for woman to give, what man no longer asks for; what unhappiness for both! For if there is one thing I should like to tell you about the Oriental woman, it is of her happiness; you have only to consider her serenity or to watch her movements to be assured of this. She is happy, because she has no need to seek about for a career; she knows very well what she wants.

The service of man is woman's greatest delight. What service, however, is this? It is even less one of intellectual companionship, than of merely meaningless household drudgery. It is a purely magical relation; a relation which was also very well understood in Europe in the days of chivalry. Women are sources of life and energy, more elemental and impersonal than men. This life is useless to themselves, it is theirs only to give to children and to poets, and if it is withheld it perishes. As well might a poet desert his life-work or a soldier his service, as a twice-born woman her personal allegiance. But no man in loving woman, howsoever passionately, howsoever nobly, makes or can make such surrender of himself to her: "I could not love thee, dear, so much, loved I not honour more." Her influence is unlimited; but she must not use it to command his service, only to inspire his greatness. It is not her reward for uttermost devotion to receive the same again in kind, but to know that he no less merges self in art. It should be needless to remark that by 'art' I do not mean any such waste of time as the painting of academy pictures, but all work creative and prepotent in the realm of ideas, all spiritual and physical knight-errantry, everything, in fact, that Nietzsche would imply by 'war.'

When man clearly spent his life in war, then woman felt that she could not do enough for him in personal service of body and soul. What we have not yet learnt is that the same relation is needed for the finest quality of life even when war has become unknown and unimaginable; the personal physical service of woman is as necessary to the true man now, as ever it was when his first duty was war. No man can achieve greatness (except as an ascetic, and then even with some danger of narrowness), whose physical environment lacks tenderness.

Everyone understands the heroism of war : we are not surprised at Lady Hamilton's adoration of Nelson. But we have outgrown war: the more civilised races, such as China, regard it with quite open contempt. What we do not yet understand is the heroism of art, the exhausting and perpetual demand which all creative work makes alike on body and soul. The artist is indeed a yogi, and must fight a continual battle for mastery of himself and his 
environment; for his work must usually be achieved in the teeth of violent and ignorant opposition, or against still more wearing apathy, in any case against the intense resistance which matter opposes to moulding force of ideas. The ardent love of women is not too great a reward for those who are faithful; but it is more than the reward of action, it is the energy without which action may be impossible.

Of course, we do already perceive the beginning of a recognition of power to prevail in concepts as more sexually attractive than power to prevail in physical conflicts. As remarked by Stanley Hall, educated woman instinctively respects and reveres the men who are expert and leaders in their chosen sphere; she may even demand such supremacy in the man to whom she would truly surrender herself. This is her power of perpetually creating in man the qualities she desires; an infinitely greater power than her own possession of those qualities could ever confer upon her.

I know not how many centuries it may require for Western men and women to escape from their industrial prison. But I do know that its bars are closing on us Orientals. Perhaps you could not be persuaded that it will ever again be desirable or possible for Western women to worship men. But I should like to ask you to pause before you attempt to industrialise, or to use your own phraseology, to emancipate, the Eastern woman. For if you should persuade her also to expend her power upon externals, there might come a time when you could nowhere on earth find proof that such women ever lived, as the ancient poets describe; you would forget that woman had ever been beautiful and passionate and shy. Deirdre, Brynhild, Alcestis, Sita, would become for you but empty names. That would be a great loss; for already you have discovered that in your public schools you " are not furnished with adequate womanly ideals in history and literature." 1

The industrial revolution in India is of external and very recent origin; we have no shortage of men; it is a sacred duty of parents to arrange a marriage for every daughter; our sexual culture is still deeply religious; Indian women do not pinch their feet or waists; they are more concerned about service than rights; they consider barrenness the greatest possible misfortune, next to widowhood; in a word, it has never happened in India that women have been judged, or have accepted, purely male standards of value. What possible service then, except in a few externals, can the Western world render to Eastern women? We think, on 
the contrary, that though it is able to teach us much of the means of life, it has everything yet to relearn about life itself.

Ananda K. Coomaraswamy.

\section{APPENDIX.}

The reader is requested to reflect upon the following quotations :-

(I) Olive Schreiner : "We take all labour for our province."

-Woman and Labour.

(2) The New York correspondent of the Manchester Guardian, in a telegram of September 24, 1912, said :-

A legislative committee has during the recess been investigating the working of factories in this State, and, according to Mr. Wagner, the chairman of the committee, the members have found the conditions revolting, especially in regard to the labour of women. Mr. Wagner said to-day: "The conditions of factory life in this State are absolutely inhuman. We found women working in blood-sodden slaughter-houses, doing work totally unfitted for women. In metal foundries women were ladling molten metal, and in twine mills inhaling dust and laying the seeds of consumption. These conditions," added Mr. Wagner, "must be altered. They are a disgrace to the State of New York. Whenever the question has come up manufacturers have assured us that the sanitation of their buildings is perfect and the conditions of labour all they ought to be. This is utterly false as regards a large number of the factories. The committee is now engaged in drafting laws, which will be presented to the next session of the Legislature, for preventing the continuance of these revolting conditions."

(3) From an article in the Athenaum, September 14, 1912, summarizing the proceedings of the Second International Moral Educational Congress at The Hague, August, 1912 :-

The treatment of moral education in the home received, perhaps, too little attention. The most notable papers on this part of the subject were those by Mrs. Bramwell Booth and Mrs. Read Muinford; both insist on the enormous importance of the training in the earliest years and on the responsibility of the method. Mrs. Booth writes: "The mother will retain the paramount influence upon the child during its first and most important years. Her unconscious influence before the birth is supreme." Mrs. Mumford says: "If the process of delibente training is delayed until school age, by that time more than fivesixths of the child's actions have become the results of habits already deeply rooted, and therefore difficult-sometime well-nigh impossible-to uproot. Right training begins in the nursery, while the child's instincts are still potential and his habits unformed." In the discussion on this part of the subject several speakers, including Madame Kergonard of Parin and M. van Ravenstein, called attention to the intimate relation between the educa. tional and the economic queation. Can the mother who works full time in a factory, and goes home to pay scant attention to her house, give the necessary time and attention to the proper upbringing of her children? 